\title{
Hemangiopericytoma in a female dog with direct invasion of abdominal cavity and pulmonary metastasis
}

\author{
Hemangiopericitoma em uma cadela com invasão direta da cavidade abdominal \\ e metástase pulmonar
}

\author{
Elisângela Olegário da Silva ${ }^{\mathrm{I}, \text { II }}$ Fernanda Romero ${ }^{\mathrm{II}}$ Kerriel Thandile Green ${ }^{\mathrm{I}}$ \\ Maria Isabel Mello Martins ${ }^{\mathrm{III}}$ Ana Paula Frederico Rodrigues Loureiro Bracarense ${ }^{\mathrm{I}}$
}

\section{ABSTRACT}

An intact adult female Poodle dog was presented with a history of an increase in volume in the left and right mammary inguinal glands. The histopathological examination revealed a proliferation of spindle cells arranged in bundles with concentric arrangements surrounding blood vessels, occasionally collapsed. Three weeks after the surgery, the animal presented a recurrence of the tumor that extended from the left inguinal mammary gland to the vulva. Necropsy revealed direct invasion of the abdominal cavity by the tumor and pulmonary metastasis. The definitive diagnosis of hemangiopericytoma was made by histopathological and immunohistochemical examination. Pulmonary metastasis of $\mathrm{CHP}$ (canine hemangiopericytoma) is rare and there is no previous report of direct invasion to the abdominal cavity as observed in the present case.

Key words: perivascular wall tumors, metastasis, lung, abdominal cavity, dog.

\section{RESUMO}

Uma cadela adulta, intacta, da raça Poodle, apresentou histórico de aumento de volume na mama inguinal direita. O exame histopatológico revelou proliferação de células fusiformes dispostas em bandas e arranjos concêntricos ao redor de vasos, os quais se apresentavam ocasionalmente colapsados. Três semanas após a cirurgia, o animal apresentou recorrência do tumor que se estendia até a vulva. No exame necroscópico, observou-se que a massa invadia a cavidade abdominal $e$ presença de metástase no pulmão. O diagnóstico definitivo de hemangiopericitoma foi realizado por meio dos exames histopatológico e imuno-histoquímico. A metástase pulmonar do hemangiopericitoma canino é rara e não há relatos prévios de invasão direta para cavidade abdominal, como observado no presente caso.

Palavras-chave: tumores da parede vascular, pulmão, cavidade abdominal, cão.
Hemangiopericytoma (HP) is an uncommon tumor in humans (TROJANI et al., 1984) and in animals (GOLDSCHMIDT \& HENDRICK, 2002) and currently included in the perivascular wall tumor (PWTs) classification (AVALLONE et al., 2007). The name hemangiopericytoma is frequently used in veterinary medicine to denominate a histological feature created by a variety of spindle cell tumors arranged in a whorl pattern, rather than a specific tumor of the pericytes (GROSS et al., 2005), due to the difficulty in identifying pericytes by their morphology and immunophenotype (GOLDSCHMIDT \& HENDRICK, 2002; GROSS et al., 2005).

The HP usually develops in dogs aged 7 to 10 years old and large breeds appear more susceptible. There is no sex predilection (GOLDSCHMIDT \& HENDRICK, 2002; GROSS et al., 2005). However, some reports showed that females are more affected than males (SANTOS et al., 2009; MARUO et al., 2012). CHP occurs most commonly in the skin around the joints of limbs, but others skin regions can also be affected (GROSS et al., 2005).

The definitive diagnosis of HP is obtained by histopathological examination. The hallmark of this tumor is the presence of perivascular whorls of fusiform cells (GOLDSCHMIDT \& HENDRICK, 2002; GROSS et al., 2005). Immunohistochemistry exams are also important as differential diagnosis from other sarcomas. However, there is no immunostaining

\footnotetext{
'Laboratório de Patologia Animal, Universidade Estadual de Londrina (UEL), 86057-970, Londrina, Pr, Brasil. E-mail: anauel02@yahoo.com.br.

*Autor para correspondência.

"Faculdade Integrado, Campo Mourão, PR, Brasil.

IIIDepartamento de Clínicas Veterinárias, UEL, Londrina, PR, Brasil. Received 05.04.13 Approved 08.16.13 Returned by the author 11.21.13 CR-2013-0613.R1
} 
specific to HP (GOLDSCHMIDT \& HENDRICK, 2002; GROSS et al., 2005). Recurrent HP show a more aggressive behavior than primary tumors, however metastases are rare (GOLDSCHMIDT \& HENDRICK, 2002; GROSS et al., 2005) and there are few reports in the veterinary literature (BOSTOCK et al., 1980, RICHARDSON et al., 1983; POSTORINO et al., 1988; HANDHARYANI et al., 1999).

An intact adult female Poodle dog was presented to the Veterinary Hospital of the Universidade Estadual de Londrina, Paraná, Brazil, with a history of increased right inguinal mammary gland. The mass measured $7 \times 8 \mathrm{~cm}$, soft in consistency and the overlying skin was ulcerated. The animal presented apathy and pain on manipulation. Thoracic and abdominal radiographs revealed no presence of metastasis.

The animal was submitted to partial mastectomy and the histological examination of the mass showed a proliferation of spindle cells arranged in bundles with concentric arrangements surrounding blood vessels, occasionally collapsed (later confirmed by immunohistochemistry exam), interspersed with moderate collagenous stroma, moderately circumscribed with infiltrative borders in deep dermis. The cells presented basophilic cytoplasm, vesicular nuclei elongated to oval, moderate to severe anisokaryosis, and one or more conspicuous nucleoli. Analysis revealed an average of 3 mitoses/10 fields $x 400$. Extensive foci of necrosis with neutrophilic infiltrates were observed. The mass showed extended to the margins of the sections examined. There was no involvement of mammary tissue. The definitive diagnosis was suggested of HP. Three weeks after, the animal presented recurrence of the tumor that extended to the left inguinal mammary gland and to the vulva with central ulcerated area. Due the worsening of the clinical condition, the dog was euthanized.

Necropsy examination was performed soon after death and gross examination revealed a white mass $(13 \times 8 \times 6 \mathrm{~cm})$ that on cut surface showed reddish and whitish areas. The mass invaded the abdominal cavity by the body wall, extending from inguinal region to ureters, adhered in the proximal third of the right ureter (Figure 1A). The ureter was thickened and dilated and right kidney showed moderate hydronephrosis (Figure 1B). A single whitish nodule $(0.3 \mathrm{~cm})$ was present in the right cranial pulmonary lobe. Tissue samples of the recurrent mass, abdominal mass and pulmonary nodule were submitted to histological evaluation and to immunohistochemical (IHC) assay. Immunostainig was performed using a polymer-based detection kit (ENVISION plus, Dako ${ }^{\circledR}$ ). Slides were incubated with antibodiesagainst PCNA (Proliferating Cell Nuclear Antigen, polyclonal, Dako ${ }^{\circledR}$, 1:200 dilution), vimentin (V9, Invitrogen ${ }^{\circledR}, 1: 100$ dilution) and factor VIII (polyclonal, Dako ${ }^{\circledR}, 1: 100$ dilution). The protocols, positive and negative controls were used following the manufacturer's recommendations. The percentage of PCNA positive cells was calculated by counting PCNA immunostained cells using the following criteria: PCNA positive cells x 100/ number of total cells ( 200 cells).

Microscopic examination of the recurrent mass, intra-abdominal mass and pulmonary nodule revealed histopathological features similar to those observed in the primary mass (Figure 1C). In IHC analysis, neoplastic cells showed strong positivity to vimentin staining and blood vessels inside whorls of neoplastic cells showed positive staining for factor VIII (Figure 1D). In the evaluation of PCNA immunoexpression, $82 \%$ of the malignant cells showed a positive immunostaining.

The differential diagnoses for hemangiopericytoma include peripheral nerve sheath tumors (PNST), fibrosarcomas, myofibroblastic fibrosarcomas, spindle cell histiocytic sarcomas, and spindle cell glomus tumors. The whorls present in PNST are not arranged around vascular structures as observed in HP. Fibrosarcomas and myofibroblastic fibrosarcomas have similar cytoplasmic and nuclear features to hemangiopericytoma, but similarly to PNST, tumor cells exhibit a whorl pattern around a collagenous center, but lack concentric perivascular whorls (GOLDSCHMIDT \& HENDRICK, 2002; GROSS et al., 2005). Spindle cell histiocytic sarcomas are often composed of a mixture of spindle cells and round large individualized cells. Similar to findings observed in PNST, the whorls are not centered on small vascular structures. Spindle cell gloms tumors are characterized by tumor cells surrounding vascular structures, but may have more prominent and plumper spindle cells than HP (GOLDSCHMIDT \& HENDRICK, 2002).

In humans and in dogs, a histologic grade and classification of the HP can be used as a diagnostic tool to predictive prognosis, recurrence and metastasis rates. This histological grade is based in the following criteria: tissue differentiation, mitotic count and quantify of necrosis and ranges from grade I to III. Grade III tumors tend to exhibit a more aggressive behavior and an overall poor diagnosis (TROJANI et al., 1984; MARUO et al., 2012). Furthermore, HP in dogs with a mitotic index above nine mitotic figures 


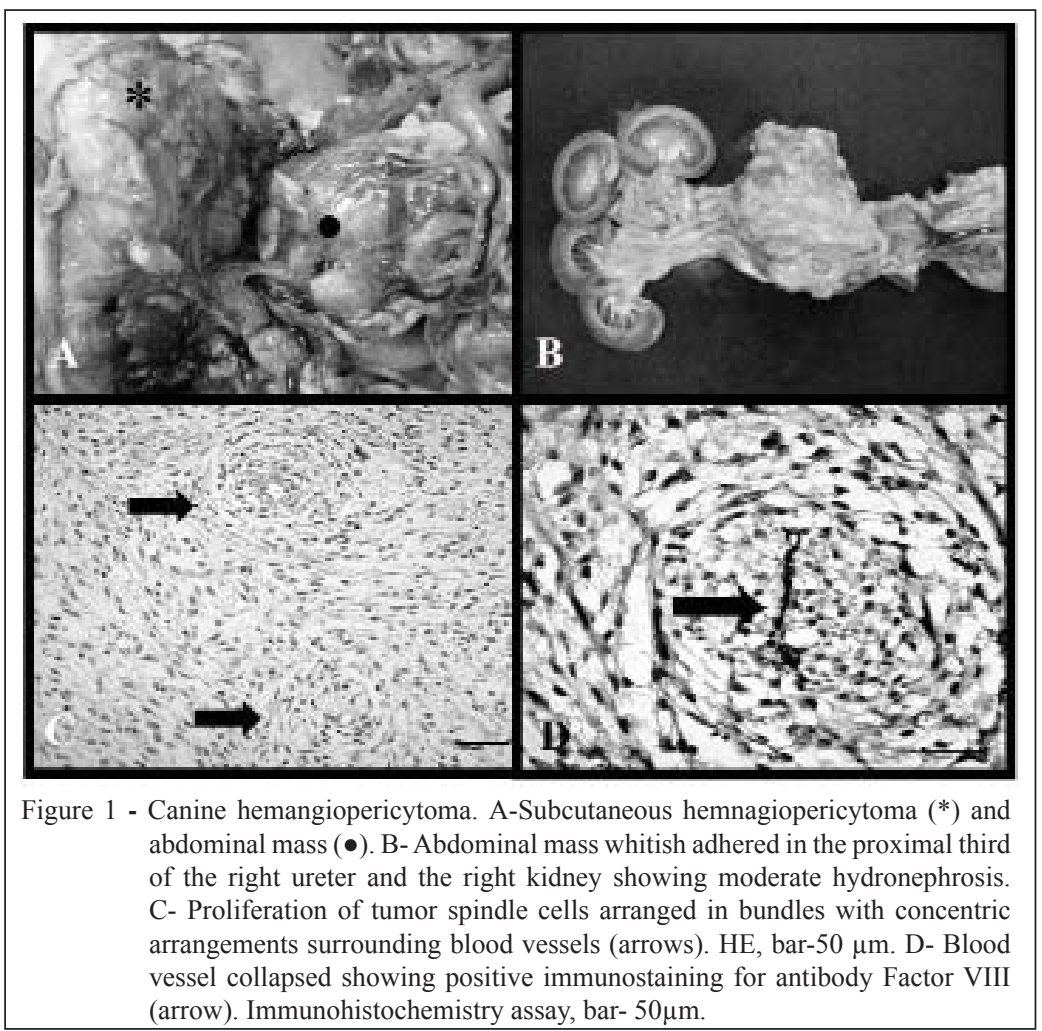

is associated with lower survival rates than averages below this index (BOSTOCK et al., 1980). In the present case, the tumor showed features consistent with grade II. Despite the intermediate features of malignancy and low mitotic index, the tumor showed a high PCNA positive expression. The quantification of cell proliferation can help in the determination of the aggressiveness of the hemangiopericytoma (SANTOS et al., 2009). In this case, the high expression of PCNA positive cells $(82 \%)$ may be associated to their aggressive behavior, with local recurrence and metastases three weeks after surgical excision.

The immunohistochemistry is useful in ruling out others spindle cell tumors wich present the whorl pattern (GOLDSCHMIDT \& HENDRICK, 2002; GROSS et al., 2005). Immunostaining for factor VIII can be used to evidence blood vessels inside whorls of neoplastic cells in CHP, whereas immunostaining for vimentin confirm the mesenchymal origin (GROSS et al., 2005). In this case, even collapsed blood vessels were evidenced by immunostaining for factor VIII. Reports about CHP describe contradictory results about immunohistochemical assay for GFAP (glial fibrillary acidic protein), S-100 protein, lysozyme, and others antibodies (PÉREZ et al., 1996; HANDHARYANI et al., 1999; AVALLONE et al., 2007; SANTOS et al., 2009), since a specific marker for pericytes is not available (GROSS et al., 2005). This limitation implies that histological evaluation continues to be the best and most precise means of making a definitive diagnosis of CHP.

The quality of surgical margins has been reported to be the most important factor in predicting local recurrences due the infiltrative behavior of HP (GROSS et al., 2005). In dogs with HP in limbs, surgical amputation is indicated, but in the present case, surgery with wide excision margins was not possible due the localization of the tumor.

Metastasis of CHP is rare and the scarce reports include the lung, chest and lymph nodes (BOSTOCK et al., 1980, RICHARDSON et al., 1983; POSTORINO et al., 1988; HANDHARYANI et al., 1999). To the best understanding of the authors, there are no previous reports regarding direct invasion of abdominal cavity by this tumor in dogs. It is important to emphasize that even without the presence of accentuated malignant features, the tumor recurred and showed locally aggressive and invasive behavior. The prognosis of CHP in abdominal cutaneous region is uncertain due the infiltrative behavior of this tumor and difficulty in performing surgical treatment with wide margins.

Ciência Rural, v.44, n.2, fev, 2014. 


\section{REFERENCES}

AVALLONE, G. et al. The spectrum of canine cutaneous perivascular wall tumors: morphologic, phenotypic and clinical characterization. Veterinary Pathology, v.44, p.607-620, 2007. Available from: <http://vet.sagepub.com/content/44/5/607>. Accessed: nov. 28, 2012. doi:10.1354/vp.44-5-607.

BOSTOCK, D.E.; JONES, T.C. Prognosis after surgical excision of canine fibrous connective tissue sarcomas. Veterinary Pathology, v.17, p.581-588, 1980.

GOLDSCHMIDT, M.H.; HENDRICK, M.J. Tumors of the skin and soft tissue. In: MEUTEN, D.J. (Ed.). Tumors in domestic animals. 4.ed. Iowa: Iowa State, 2002. Cap. 2, p.45-117.

GROSS, T.L et al. Mesenchymal neoplasms and other tumors. In: Skin diseases of the dog and cat: clinical and histopathologic diagnosis. 2.ed. Iowa: Blackwell Publishing Company, 2005. Part II, p.709-772.

HANDHARYANI, E. et al. Canine hemangiopericytoma: an evaluation of metastatic potential. Journal of Veterinary Diagnostic Investigation, v.11, p.474-478, 1999. Available from: $<$ http://vdi.sagepub.com/content/11/5/474>. Accessed: nov. 28, 2012. doi: $10.1177 / 104063879901100517$.

MARUO, T. et al. Evaluation of intraoperative radiation therapy for incompletely resected or recurrent canine hemangiopericytoma: seventeen cases. Internal Journal of Applied Research in Veterinary Medicine, v.10, p.132-136, 2012.

PÉREZ, J. et al. Immunohistochemial characterization of hemangopericytoma and others spindle cell tumors in the dog. Veterinary Pathology, v.33, p.391-397, 1996. Available from: $<$ http://vet.sagepub.com/content/33/4/391>. Accessed: nov. 29, 2012. doi: $10.1177 / 030098589603300404$.

POSTORINO, N.C. et al. Prognostic variables for canine hemangiopericytoma: 50 cases (1979-1984). Journal of American Animal Hospital Association, v.24, p.501-509, 1988.

RICHARDSON, R.C. etal. Metastatic canine hemangiopericytoma. Journal of American Veterinary Medical Association, v.182, p.705-706, 1983.

SANTOS, S.V. et al. Canine hemangopericytomas: cell proliferation and apoptosis in the perivascular, storiform and epithelioid histological subtypes and their significance for prognosis. Brazilian Journal of Veterinary Pathology, v.2, p.2328, 2009. Available from: <http://www.abpv.vet.br/paginas site/ default.asp?P=BJVP\&PAG_SEQ=4286>. Accessed: nov. 30, 2012

TROJANI, M. et al. Soft-tissue sarcomas of adults: study of pathological prognostic variables and definition of a histopathological grading system. International Journal of Cancer, v.33, p.37-42, 1984. 